\title{
José Fillipi: o italiano pioneiro do cinema no Maranhão ${ }^{1}$
}

\author{
Marcos Fábio Belo MATOS ${ }^{2}$
}

\begin{abstract}
Resumo:
O cinema no Maranhão deu seus primeiros passos em 1898, três anos depois que, em Paris, os irmãos Lumière apresentaram ao mundo o que seria "a maior novidade fin-de-siècle": o cinematógrafo. Nos primeiros 11 anos de atividade em terras maranhenses, ele foi totalmente ambulante, sendo as sessões, sazonais, dadas quase sempre no antigo Teatro União (hoje Arthur Azevedo). Durante o ciclo ambulante, passaram por São Luís 14 aparelhos cinematográficos, dos mais variados nomes. Mas um deles, além de apresentar as "vistas", animadas e fixas, fez também o que seria o primeiro filme maranhense. O nome do projecionista-diretor-empresário de cinematografia era José Fillipi, italiano, que esteve em São Luís, apresentando o seu Bioscópio Inglês, de 13.07 a 08.08.1902. É a história desse projecionista, seu aparelho e a façanha de ser o pioneiro do cinema maranhense que enfocamos neste artigo. Uma aventura que, literalmente, uniu dois mundos.
\end{abstract}

Palavras-chave:

Cinema. Cinema ambulante. Maranhão. Itália.

\section{José Fillipi: the italian pioneer of the Maranhão cinema}

\begin{abstract}
:
The movie theater in Maranhão began in 1898, three years after than Lumiere brothers in Paris showed the world what would be "the biggest news fin-de-siècle": the cinematograph. In the first 11 years of activity in Maranhão, the movie theater was totally ambulant, with the seasonal sessions usually taking place in the old Union Theater (nowadays, Arthur Azevedo). During the ambulant cycle, 14 cinematographic apparatuses, of the most varied names, passed through São Luís. But one of them, besides presenting the "sights", animated and fixed, also did what would be the first Maranhão film. The name of the projectionist-director-businessman of cinematography was Jose Fillipi, Italian, who was in São Luís, presenting his English Bioscope, from 13.07 to 08.08.1902. It is the history of this projectionist, his apparatus and the feat of being the pioneer of the Maranhão cinema that we focus in this article. An adventure that literally united two worlds.
\end{abstract}

Key-words:

Cinema. Ambulant cinema. Maranhão. Italy.

\section{José Fillipi: el italiano pionero del cine en Maranhão}

\section{Resumen:}

En Maranhão, el cine dio sus primeros pasos en 1898, tres años después que, en Paris los hermanos Lumière presentaran al mundo lo que sería "la mejor novedad fin-de-siècle": el cinematógrafo. En los 11 primeros años de actividad en tierras maranhenses, fue completamente ambulante, siendo las sesiones, expuestas en un corto periodo de tiempo en el antiguo Teatro União (hoy Arthur Azevedo). En este periodo, pasaron por São Luis 14 aparatos cinematógrafos, con los más variados nombres. Sin embargo, uno de ellos, además de presentar las "vistas" animadas y fijas, hizo también lo que sería la primera

\footnotetext{
${ }^{1}$ Artigo publicado nos Anais do $1^{\circ}$. Simpósio Internacional Brasil-Itália, na Universidade Estadual do Maranhão, São Luís, de 26 a 28 de agosto de 2015 e do $6^{\circ}$. Encontro Regional Sul de História da Mídia, em Ponta Grossa/PR, de 15 a 17 de junho de 2016.

2 Professor do Curso de Comunicação Social - Jornalismo, da Universidade Federal do MaranhãoImperatriz. Mestre em Comunicação e Cultura pela Universidade Federal do Rio de Janeiro, Doutor em Linguística e Língua Portuguesa pela Universidade Estadual Paulista-Araraquara e Pós-doutor em Comunicação pela Unisinos. Autor dos livros: “...E o cinema invadiu a Athenas: a história do cinema ambulante em São Luís (1898-1909)", publicado em 2002, e "Ecos da Modernidade: uma análise do discurso sobre o cinema ambulante em São Luís”, publicado em 2016.
} 
película maranhense. El nombre del proyeccionista - director - empresario del cinematógrafo era José Fillipi, italiano, que estuvo en São Luis presentando su Bioscope Ingles, de 13.07 hasta 08.08.1902. Es la historia de este proyeccionista, su aparato y la hazaña de ser el primer pionero del cine maranhense que enfocamos en este artículo. Una aventura que, literalmente, unió dos mundos.

Palabras clave:

Cinema. Cine Ambulante. Maranhão. Italia.

\section{INTRODUÇÃO}

Cronofotógrafo de Demeny. Este é o nome da máquina que inaugurou a atividade cinematográfica no Maranhão. O ano era 1898, três anos depois que os irmãos Lumière fizeram a histórica apresentação do seu "Cinematógrafo", no dia 28 de dezembro de 1895, num salão do Grand Café do Boulevard des Capucines, em Paris (FOIRET; BROCHARD, 1995). O aparelho é um dos muitos equipamentos de nomes estranhos que povoaram o início do cinema no mundo. Foi criado por George Demenÿ, cientista e inventor francês, que, assim como muitos outros pesquisadores do final do século XIX, também quis fazer fortuna e fama com o negócio das imagens em movimento - tirá-las do laboratório e pô-las nas ruas, se possível em tela grande. O Cronofotógrafo, assim como o Bioscópio, o Vitascópio, o Eidoloscópio, o Fantoscópio e muitas e muitas outras máquinas de nomenclaturas estrambóticas, perdeu para o Cinematógrafo pela nominação do espetáculo e pela paternidade da primeira grande invenção de massa do século XX.

Para nossos olhos e mentes pós-modernos, acostumados à aceleração do tempo e à pulverização das distâncias, três anos pode parecer muito tempo. Mas para o final do século XIX, quando apenas engatinhavam as ferrovias e demais sistemas de transportes terrestres, sobretudo em países periféricos, como o Brasil, e numa realidade em que quase todo o transporte era feito por rio e mar, três anos era muito rápido. E foi com essa rapidez que o cinema se espalhou pelo mundo, tão logo os aparelhos começaram a ser inventados e comercializados (vendidos ou alugados).

Concorrendo com a invenção dos Lumière, uma série de outros aparelhos também ganhava países, estados, cidades e vilas mundo afora, pois a lógica do negócio era levar a "última invenção deste fim de século em matéria de maravilhas" (como foi denominado o Cronofotógrafo pelos jornais ludovicenses ${ }^{3}$ ) aos mais distantes lugares, onde ele ainda pudesse ser novidade e fazer uma bela temporada em teatros, salões, circos, salas ou ao ar livre. Para se ter uma ideia da mentalidade

\footnotetext{
${ }^{3}$ Ludovicense é o adjetivo gentílico que designa os nascidos em São Luís, capital do Maranhão.
} 
comercial que rondava o nascimento dessa diversão, um dos anúncios dos Lumière sobre a comercialização dos seus aparelhos dizia, em maio de 1896:

Quinetoscópio Fonógrafo Continental. Equinetógrafo Pathé. Tipo Cinematógrafo. Equipamento de projeção movimentada. Ch Pathé, Paris, Cours de Vincennes, 72. Fortuna certa em poucos meses de exploração. $\mathrm{O}$ aparelho funciona nos principais estabelecimentos de Paris. (MANNONI, 2003, p. 425, grifo nosso).

Foi por esse sonho de riqueza repentina com tal novidade, nunca vista em muitos rincões do país, que muita gente se encantou. E essas máquinas de realidade eram geralmente levadas pelas mãos dos ambulantes, como bem detalhou Máximo Barro (2000), que se espalharam pelas mais diversas localidades, em pouco tempo: Manaus, Maceió e Juiz de Fora, Niterói, Curitiba, Campinas, Mococa, Salvador, Ribeirão Preto, Petrópolis e João Pessoa, em 1897; Belo Horizonte, Bragança Paulista, Natal, Aracaju e Araras, em 1898; as grandes cidades do Vale do Paraíba, em 1899. Antes, porém, ele já tinha chegado ao Rio de Janeiro, em meados de 1896, e em São Paulo, em fevereiro de 1897, como registra Vicente de Paulo Araújo, em dois estudos preciosos, respectivamente: "A bela época do cinema brasileiro" (1985) e "Salões, circos e cinemas de São Paulo" (1981). A projeção do Rio, inclusive, é considerada por todos os historiadores da arqueologia do cinema como a primeira do Brasil e da América do Sul, como registra Capellaro e Ferreira (1996):

(...) fica evidenciado que o evento 'Omniógrafo' constitui a primeira projeção pública de cinematografia animada sobre uma tela e para vários espectadores no Brasil. E também na América do Sul, pois a primeira projeção na Argentina ocorreu em Buenos Aires em 18 de julho de 1896. (CAPELLARO; FERREIRA, 1996, p. 20).

E como se desobrigavam esses "empresários da cinematografia" da sua função de levar o seu "aparelho de fantasia" pelo mundo? O panorama dessas exibições é dado por Máximo Barro (2000):

Os aparatos das sessões cinematográficas brasileiras limitavam-se a um lençol ou outro pano branco, estirado por pregos, que servia de tela ou alvo, como era então chamada. O calor da sala, mesmo no inverno, propiciava $\mathrm{o}$ alargamento do tecido, obrigando $\mathrm{o}$ projecionista a molhá-lo com mangueira ou regador, a cada tanto, para novamente estirá-lo e dar mais brilho às imagens, mercê das propriedades que a água possui quando atravessada pela luz. As sessões duravam ordinariamente 30 minutos. Formatados por 5 ou 6 filmes de 47 segundos, chegaríamos a um total de 5 minutos. Com mais outros 10 para saída e entrada do público, sobrariam sempre 15, preenchidos pela personalidade carismática destes aventureiros ignorados pelos historiadores brasileiros, carregando e descarregando 
filmes, vistos como feiticeiros que tinham o condão de fazer a fotografia mover-se. [...]

O projetor era ordinariamente instalado no centro da sala ou teatro, à mostra de todos. Apenas quando o evento se abrigava em teatros que tivessem um bom recuo de palco, é que assistia-se o espetáculo por retro projeção. Quem assistisse um espetáculo cinematográfico pela primeira vez, comumente colocavam-se [sic] de frente para o aparelho e de costas para a tela, julgando-o receptor e não transmissor de imagens. Durante a projeção do trecho de 47 segundos, no escuro, o filme caía no chão, ou no máximo, era recolhido num cesto, porque os aparelhos ainda não dispunham de carretel receptor. Ao término da rapidíssima projeção de cada assunto, as luzes eram acesas e o projecionista calmamente enrolava o filme depositado no cesto ou chão. Em seguida, iniciava o carregamento no projetor, do trecho seguinte, renovando-se o processamento anteriormente visto. Desse modo, metade do tempo da sessão era perdida nesse ritual. Perdida, é bom deixar claro, para o nosso conceito atual, porque para o espectador da época, aquilo, também, era ingrediente do encantamento da novidade. (BARRO, 2000, p. 11).

Foi exatamente um desses ambulantes que chegou a São Luís com o seu Cronofotógrafo, apresentando espetáculos noturnos e diários por 45 dias, numa sala em frente ao Teatro São Luiz, hoje Arthur Azevedo, o mais importante da cidade também naquela época. O nome do proprietário e empresário da diversão era Moura Quineau, antigo fotógrafo que, segundo os jornais, já havia residido em São Luís e que, pelo visto, como muitos outros fotógrafos mundo afora, havia trocado a fotografia pela nova invenção, mais comercial porque novidadeira. Sua maquinaria foi assim apresentada pelo jornal Pacotilha, então o mais importante de São Luís, com uma tiragem de 2.000 exemplares e circulação diária ${ }^{4}$ :

O senhor Moura Quineau, habil photographo que aqui já residio, trouxe agora a esta capital a ultima invenção deste fim de seculo em materia de maravilhas.

É o cronophotographo de Demeny, apparelho que reproduz a photographia animada com todas [sic] os movimentos naturaes.

É realmente curioso e digno de ver-se o cronophotographo que o sr. Moura Quineau vae exhibir ao publico por estas noites, no proximo domingo, á rua do Sol, em frente ao theatro. (PACOTILHA, 09 abr. 1898, s.p.).

\footnotetext{
${ }^{4}$ Por uma escolha metodológica, que consiste em preservar, o mais possível, a autenticidade da coleta das informações nos jornais de época pesquisados (Pacotilha, Diário do Maranhão e O Federalista), as transcrições trazem a grafia da época. Outro dado relevante a ser registrado é o fato de que esta pesquisa, originalmente, uma dissertação de mestrado, para sua consecução, analisou todas as edições dos jornais Pacotilha, Diário do Maranhão e o Federalista, entre 1895 e 1909, período do cinema ambulante em São Luís, disponíveis no setor de microfilme da Biblioteca Nacional, no Rio de Janeiro, e ainda na Biblioteca Pública Benedito Leite e no Arquivo Público (ambos em São Luís), estes dois últimos possuindo, à época (1998-2000), edições em papel.
} 
Moura Quineau foi o responsável por iniciar um ciclo, o Ciclo do Cinema Ambulante, em São Luís (e, por extensão, no Maranhão, pois não há registros, nessa fase, de projeções em outros municípios do estado). Este ciclo perdurou por 11 anos e foi formado por 14 aparelhos cinematográficos, que visitaram a cidade 16 vezes, conforme se vê na Tabela 1 abaixo:

Tabela 1 - Relação de aparelhos que passaram por São Luís

\begin{tabular}{|c|c|c|}
\hline APARELHO & ANO & PERMANÊNCIA \\
\hline Cronofotógrafo de Demeny & 1898 & $07.04 .98-15.05 .98$ \\
\hline Bioscópio Inglês & 1902 & $13.07 .02-09.08 .02$ \\
\hline Cinematógrafo Alemão & $1902-3$ & $18.04 .02-01.03 .03$ \\
\hline Bioscópio Ítalo-Brasileiro & 1903 & $24.10 .03-12.11 .03$ \\
\hline Cinematógrafo Hervet (primeira passagem) & 1904 & $30.04 .04-13.05 .04$ \\
\hline Cinematógrafo Kaurt & \multirow[t]{3}{*}{1906} & $27.01 .06-02.02 .06$ \\
\hline Aletorama & & $16.06 .06-28.06 .06$ \\
\hline $\begin{array}{lll}\text { Cinematógrafo } & \text { Parisiense } & \text { (primeira } \\
\text { passagem) } & & \end{array}$ & & $28.08 .06-11.09 .06$ \\
\hline Cinematógrafo Hervet (segunda passagem) & \multirow[t]{4}{*}{1907} & $16.03 .07-16.04 .07$ \\
\hline $\begin{array}{lll}\text { Cinematógrafo } & \text { Parisiense } & \text { (segunda } \\
\text { passagem) } & & \end{array}$ & & $20.04 .07-22.04 .07$ \\
\hline Cinematógrafo Gaumont & & $14.08 .07-16.08 .07$ \\
\hline Teatro Campestre & & 06.10 .07 \\
\hline Cinematógrafo Falante /Maurice e Linga & \multirow[t]{3}{*}{1908} & $30.01 .08-12.02 .08$ \\
\hline Cinematógrafo Fontenelle & & $07.03 .08-10.05 .08$ \\
\hline Cinematógrafo Norte-Americano & & $05.09 .08-29.09 .08$ \\
\hline Cinematógrafo Pathé & 1909 & $01.05 .09-08.05 .09$ \\
\hline
\end{tabular}

Fonte: Matos (2002).

A história de cada um desses aparelhos, suas vicissitudes, seus erros e acertos está contada em nosso trabalho “...E o cinema invadiu a Athenas: a história do cinema ambulante em São Luís (1898-1909)", editado em 2002 pela Fundação Municipal de Cultura de São Luís. 


\section{José Fillipi no Maranhão}

O italiano J. Fillipi chegou em São Luís em 1902, quatro anos depois que Moura Quineau deixou a cidade com o gosto da novidade do cinema. Foi o segundo aparelho cinematográfico a ser visto na capital. E, a julgar pelo que disseram os jornais locais (MATOS, 2016), o de maior qualidade técnica e, por conseguinte, de melhor espetáculo. A Pacotilha, por exemplo, que então era o jornal mais tradicional e mais lido da capital, fez-lhe muitos elogios, comentando a estada do empresário em Belém do Pará:

Na capital paraense, onde esteve, a empreza do sr. José Felippi conquistou muitos applausos, havendo sempre grande numero de espectadores para os seus trabalhos. A imprensa de Belem fez-lhe optimas referencias, quando tinha occasião de noticiar seus espectaculos. (PACOTILHA, 05 jul. 1902, s.p.).

Era a lógica do período os espetáculos culturais terem São Luís na rota das suas apresentações pelo Norte-Nordeste. Isso porque os navios que os traziam vinham de Fortaleza e passavam por São Luís, subindo até Belém e Manaus, ou na direção oposta. O Bioscópio Inglês foi o primeiro aparelho cinematográfico a ocupar o Teatro S. Luiz, inaugurando uma tradição de espetáculos desse tipo naquele palco. Antes, como dissemos, o Cronofotógrafo de Moura Quineau ocupou uma sala em frente ao Teatro, pelo fato de este estar, na época da estreia do seu aparelho na cidade, ocupado pela prestigiada companhia teatral Dias Braga, nacionalmente conhecida (MATOS, 2002).

Sobre a estreia do Bioscópio Inglês, os três mais importantes jornais de São Luís à época, a saber, a Pacotilha, o Diário do Maranhão e O Federalista, expuseram as melhores impressões, como registram os relatos abaixo:
Bioscope Inglez -
Certo, não podiam ser melhor empregadas as horas que o nosso publico hontem á noite no $<$ S.Luiz $>$, a assistir a estréa da Companhia d'Artes e Bioscope Inglez.
Já havíamos apreciado a exhibição de diversos cinematographos ${ }^{5}$, mas nenhum nos agradou tanto como esse do sr. J. Filippi, que tem a

\footnotetext{
5 Avalia-se que esta seja uma referência, talvez hiberbolizada, à memória do cronofotógrafo e às experiências do cinematógrafo alemão, que serão abordadas adiante, neste artigo. O cotejamento dos jornais, feito para esta pesquisa, não registra, além desses dois aparelhos citados, nenhuma outra passagem de cinematógrafos por São Luís, de maneira que o autor desta nota não poderia dizer que a cidade já havia apreciado diversos cinematógrafos. Outra possibilidade é o autor estar se referindo a si próprio, utilizando o plural de modéstia, e citando as suas experiências particulares como espectador do
} 
superioridade de funccionar com luz electrica e de dispor de photographias magnificas, duma nitidez e perfeição admiraveis. Todas as vistas, animadas ou fixas, comicas ou não, agradaram sobremaneira, tanto que os applausos arrebentavam de vez em quando (...)

Durante a exhibição do bioscope, a orchestra executou belissimos trechos de musica.

Terminou o espectaculo ás 11 horas, estando o interior do theatro iluminado a luz electrica.

(PACOTILHA, 14 jul. 1902, s.p.).

\section{Espectaculo -}

Teve regular concorrencia o de hontem, no Theatro S. Luiz, estréa da Companhia de Arte e Bioscope Inglez da empreza J. Filippi.

Foi a agradavel diversão dividida em 3 partes, tendo o publico apreciado e gostado muito do trabalho exhibido.

Bonitas vistas fixas e animadas, destas ultimas a $1^{\text {a }}$ parte serias, e todas de linda perspectiva, e a $2^{a}$ de comicas, que muitos applausos mereceram e provocaram muita risada.

(...)

De bello effeito a luz electrica que deu á grande sala a mais surprehendente illuminação, e com poucos focos. O publico retirou-se satisfeito.

(DIÁRIO DO MARANHÃO, 14 jul. 1902, s.p.).

Bioscopio -

Magnifico, esplendido mesmo, é o apparelho que possue o sr. J. Filippi, director da Companhia d'Artes Bioscopio Inglez, que actualmente trabalha no nosso S. Luiz.

(...)

Maravilhosas as noites de hontem e ante-hontem no nosso S. Luiz. (...) $\mathrm{O}$ Theatro nas duas noites esteve no interior todo illuminado a luz electrica.

(...)

O nosso publico que gosta do que é bom e que sabe apreciar o que é bello não deve perder occasião de ir ao S. Luiz e admirar scenas lindissimas.

(O FEDERALISTA, 15 jul. 1902, s.p.).

Uma conjunção de fatores fez com que o Bioscópio Inglês galgasse o sucesso que os jornais registraram, em São Luís. Na avaliação de Matos (2002), os principais foram:

aparelho em outros lugares. Isso, no entanto, ficará no terreno das elucubrações, pois o trecho não deixa efetivar uma análise mais precisa. 
a) Em primeiro lugar, havia um hiato de quatro anos que separavam o Cronofotógrafo de Demeny do novo aparelho, o que fez aguçar a curiosidade da população;

b) Em segundo lugar, a cidade estava saindo de uma epidemia de peste bubônica, período em que nenhuma companhia de teatro ou outra diversão externa aportou no Cais da Sagração, para aliviar o sofrimento dos ludovicenses, maltratados pela peste - e o Bioscópio Inglês foi o primeiro entretenimento pós-epidemia, o que o ajudou a levar espectadores ao teatro;

c) Em terceiro lugar, a própria qualidade técnica do aparelho, por si só, já garantia a anuência do público - funcionava à luz elétrica; tinha uma grande quantidade de vistas (como então eram chamados os filmes), fixas e animadas, sérias e cômicas, de ótima nitidez; o próprio teatro foi todo iluminado à luz elétrica, uma atração à parte;

d) Em quarto lugar, a habilidade do senhor José Fillipi como divulgador ficou registrada pelos jornais: sua cortesia, suas estratégias de marketing, sua amabilidade, seu trato com a imprensa - distribuindo convites, indo às redações, dando espetáculos gratuitos (chamados de benefícios).

e) E, por fim, em quinto lugar, o Bioscópio Inglês sofreu uma verdadeira perseguição por parte do senhor Bernard Bluhm, um alemão que morava em São Luís e que, tempos antes, havia adquirido um cinematógrafo e fez de tudo para atrapalhar os planos do italiano, colhendo como resultado a solidariedade do público ao proprietário do Bioscópio Inglês.

Algumas ações que fez o italiano José Fillipi para conseguir uma boa performance na capital do Maranhão:

a) Anunciou o seu Bioscópio como um "divertimento para as famílias", o que fazia aumentar, consideravelmente, o público dos seus espetáculos;

b) Fez um trabalho de relações públicas do seu espetáculo, pela imprensa como deixa entrever a nota de O Federalista, de 11 jul. 1902, que diz: "Veio pessoalmente visitar-nos o distincto cavalheiro sr. G. Filippi, director da Companhia d'Arte e Bioscopio Inglez, e mostrou-nos o programma de suas representações". Tal ação era de fundamental importância para que a 
imprensa local pudesse assistir aos espetáculos de graça e, depois, fazer uma boa avaliação e divulgação e, com isso, garantir muitos ingressos vendidos;

c) Promoveu, em 23 jul. 1902, uma sessão especial para as crianças, com uma casa cheia, na qual recebeu dois buquês de flores, sendo ovacionado pela petizada. Esta sessão foi, na verdade, um benefício em favor da construção de um "hospital para os lázaros" e para o socorro a um grupo de famílias desabrigadas da cidade de Caxias, interior do Maranhão, cujas casas foram destruídas num incêndio;

d) Participou, como número agregado, das comemorações da adesão do Maranhão à Independência do Brasil, em 28 de julho, dividindo o palco com discursos políticos, orquestra, peças teatrais;

e) No encerramento da sua temporada, deu ainda mais dois outros beneficios (espetáculos em que o valor arrecadado de bilheteria era revertido em função de alguma causa, em geral, humanitária): um para a Associação Tipográfica Maranhense, em 05 ago. 1902 e outro para as "famílias pobres" da cidade, em 09 ago. 1902, sendo esta a sua última sessão, e que foi assim retratada pelo Diário do Maranhão: "É a despedida da Companhia d'Arte, que assim deixa a melhor recordação de sua passagem por esta capital” (DIÁRIO DO MARANHÃO, 09 ago. 1902, s.p.).

\section{A primeira filmagem}

Os diversos aparelhos cinematográficos que foram inventados, entre 1895 e 1896, anos de ebulição das muitas "descobertas" do cinema, dos muitos patenteamentos, das muitas disputas pela paternidade da invenção, foram sendo aperfeiçoados, até chegarem ao modelo padrão, que acabou por se pulverizar pelo mundo: o dos aparelhos que, a um só tempo, filmavam e projetavam, que Mannoni (2003) denomina de "reversíveis". O cinematógrafo dos irmãos Lumière parece ser o modelo mais bem acabado desse grupo. Mas havia também, por exemplo, o próprio Cronofotógrafo, aperfeiçoado por Demenÿ e Gaumont e depois redenominado de Biógrafo; o Quinetógrafo, de De Bedts; e alguns Bioscópios, que ostentavam a mesma propriedade. Sobre esse último, diz um folheto de propaganda que ele seria capaz de

(...) nas famílias, conservar os registros vivos dos ancestrais, bastando 
um giro de manivela para que as crianças vejam seus avós e voltem a ver seus próprios rostos de bebê, uma ideia suficientemente original para atrair os amadores (...) A par dessas recreações, o bioscópio também pode ensinar os movimentos do homem e dos animais tanto na escola quanto no lar. (MANNONI, 2003, p. 432).

Assim como fazia parte da lógica do entretenimento comprar ou alugar um aparelho cinematográfico, também era comum que os empresários-projecionistas fizessem filmagens por onde iam passando, até mesmo para ampliar o seu catálogo de opções de exibição. Os filmes dessa época, como se sabe, não tinham qualidade narrativa, o que só vai acontecer a partir de 1909, quando entra em cena, no cinema, o gênio inventivo de George Meliès, conforme registrou Flávia Cesarino Costa, no seu "O Primeiro Cinema".

O primeiro cinema é, sobretudo, um processo de transformação transformação que é visível na evolução técnica dos aparelhos e na qualidade das películas, na rápida transição de uma atividade artesanal e quase circense para uma estrutura industrial de produção e consumo, na incorporação de parcelas crescentes do público. E, paralelamente, o primeiro cinema inclui também as transformações formais na linguagem que este contexto propicia. (COSTA, 2005, p. 35-6).

Foi Meliès quem inventou a narratividade do cinema. Antes dele, os filmes não eram a atração do espetáculo e, dessa forma, podiam ser apresentados em qualquer sequência, enquadrados em qualquer temática, cortados para fazerem dois ou mais, muitos inclusive eram rodados em sentido contrário, para provocar graça na plateia, pois nessa primeira fase o que interessava era o funcionamento da máquina (MATOS, 2002). Só para não esquecer: os espetáculos eram "de Cinematógrafo", "de Bioscópio", de "Aletorama" - a máquina sempre em evidência, como a grande novidade; os filmes eram apenas os recursos para fazê-las funcionar... Outro detalhe importante, que reforça esse argumento: em toda a fase desse primeiro cinema, na grande maioria dos espetáculos, os aparelhos ficavam à mostra do público, que se impressionavam em ver o seu funcionamento. Nos espetáculos dados pelos aparelhos no Teatro S. Luiz, eles ficavam, via de regra, no centro do palco - como registra essa notícia da Pacotilha, de 23 abril de 1907, sobre uma performance do Cinematógrafo Gaumont, que se exibiu no Teatro S. Luiz, já pelo fim do Ciclo Ambulante:

Cinematographo Parisiense -

Por ter afrouxado, com a trepidação do apparelho, um parafuso da engrenagem, uma das rodas dentadas desprendeu-se em plena exhibição de uma fita, no espectaculo de hontem, e rolou pelo palco 
até ao panno, dando algum trabalho para procural-a na escuridão.

Collocada novamente no logar (mas sem o parafuso, que não foi possivel encontrar-se) dentro de pouco tempo imprensou o dedo de um dos ajudantes, occasionando segunda interrupção.

Recomeçado o serviço, no fim de poucos minutos esmagou o dedo de um segundo ajudante, dando, em resultado, terceira interrupção e consequente pateada do publico, que ignorava a serie de desastres com que lutava o empresario, sempre solicito em agradal-o.

O espectaculo teve diminuta concorrencia.

(PACOTILHA, 23 abr. 1907, s.p.).

Um dos principais motivadores dessa expansão das filmagens pelo mundo foram mesmo os Lumière:

\begin{abstract}
Apesar desse triunfo [o sucesso da primeira exibição pública] e não sem algumas hesitações, Louis Lumière finalmente optou por manter a exclusividade de sua câmera reversível. Ela não mais seria colocada à venda. Lumière confiou a seus operadores-projecionistas a tarefa de montar o Catalogue des vues pour cinematografe [Catálogo de vistas para o cinematógrafo] e de mostrá-lo pelo mundo afora. (MANNONI, 2003 , p. 449 , grifos do autor).
\end{abstract}

Iam, então, os representantes dos Cinematógrafos Lumière e demais concorrentes pelos mais recônditos lugares do planeta, ao mesmo tempo dando sessões em circos, salas, salões, igrejas, teatros (luxuosos ou populares), praças públicas e onde mais permitissem e pudessem pagar e ampliando o seu leque de filmes, que eram enquadrados no gênero "ao natural", como constata esta nota da Pacotilha, de 24.04.1909, sobre uma sessão do Cinematógrafo Pathé, justamente o último aparelho a passar por São Luís, encerrando o ciclo do Cinema Ambulante:

Cinematographo Pathé -

Effectuou-se hontem á noite a experiencia de fitas novas, chegadas hontem mesmo pelo <commandatuba>, para o apparelho cinematographico instalado num dos departamentos do F.A. Clube.

A experiencia deu o mais satisfactorio resultado, funccionando o motor e o apparelho a contento geral e notando-se muita fixidez na luz.

Hoje, realisar-e-á a primeira funcção, começando ás 8 horas, em sessões de meia em meia hora.

Do programma consta: o lançamento do <Minas Geraes $>$, ao natural; um brazileiro em Paris; Por um collar; Uma ama modelo; Festa gaucha no Leme (Exposição Nacional) ao natural, e Sports na Suissa, ao natural.

Haverá bondes á porta, para a cidade, apoz cada sessão.

(PACOTILHA, 24 abr. 1909, s.p., grifo nosso).

O Bioscópio Inglês do senhor José Filippi, ao que tudo indica, tinha a 
característica de ser uma máquina reversível. O registro que ficou da sua passagem por São Luís, pelos jornais, traz uma nota curiosa, de $O$ Federalista, datada de 29 de julho de 1902. Era um registro da festa da noite anterior, no Teatro S. Luiz, em comemoração à adesão do Maranhão à Independência do Brasil. Ao que tudo indica, uma festa de pompa e circunstância. A nota traz o seguinte trecho:

(...) Antes de dar comêço ao terceiro acto que foi de Bioscopio Inglez o sr. Filippi, fez descer um panno no qual havia a seguinte saudação:

$<$ A Companhia d'Arte congratulando-se com o patriotico publico Maranhense, sauda-o pela data brilhante que hoje festeja.>

O primeiro quadro exhibido foi o do grupo da Oficina dos Novos sendo secundado por tres retratos de brasileiros: Augusto Severo, João de Deus e Benjamin Constant.

As vistas animadas agradaram geralmente.

(O FEDERALISTA, 29 jul. 1902, s.p.).

Acreditamos ser esta a primeira filmagem feita em terras maranhenses. Por dois motivos: em primeiro lugar, antes do Bioscópio, como vimos, apenas o Cronofotógrafo de Démeny havia sido exibido em São Luís, e não há nenhum registro de tomadas de vistas nem de exibição de assuntos locais; em segundo lugar, mesmo que, simultaneamente, o Cinematógrafo Alemão, do senhor Bernard Bluhm, tenha sido exibido com o Bioscópio, este vinha a ser um aparelho de muito má qualidade, a julgar pelos infortúnios que os jornais noticiavam sobre ele, dando conta dos cancelamentos dos espetáculos anunciados, o que pode ser conferido no comentário de $O$ Federalista, a respeito dos artifícios do senhor Bluhm para atrapalhar a performance do Bioscópio Inglês:

Dizem que o sr. Bernard Bluhm exhibirá amanhã e depois o seu cinematographo [no Teatro S. Luiz], deixando assim de dar funcção o Sr. J. Filippi.

Sabemos a ultima hora que o Sr. Bluhm quer privar o Sr. J. Filippi de dar espectaculo hoje.

Nada aproveitará ao sr. Bluhm, garantimos, a perseguição que implacavelmente tem movido ao Sr. J, Felippi. (...)

$\mathrm{O}$ sr. Bluhm deve lembrar-se de que o sr. Filippi tem nos proporcionado agradabilissimas noites, satisfazendo amplamente ao publico, e que é uma crueldade, além de ser uma falta de respeito e consideração, querer privar-nos desse praser. Basta ter-nos privado das noites de sabbado e domingo.

As experiencias que até hoje tem feito, devem lhe ter dado bastante conviç̧ão de que ou seus apparelhos não prestam ou S.S nada entende dessa coiza.

Ora, sendo assim, para que nos priva daquilo que nos agrada? 
O Theatro não é propriedade de Bluhns e C., e nós não nos damos bem com a impostura que nos arranca um praser.

(O FEDERALISTA, 18 jul. 1902, s.p., grifo nosso).

Desta forma, há uma possibilidade muito real de ser mesmo aquele retrato filmado da Oficina dos Novos o primeiro "filme" maranhense. A Oficina dos Novos era, na época, a principal agremiação literária da capital, formada por escritores de prestígio local e liderada por Antônio Lobo, professor, jornalista e intelectual, que, seis anos depois, fundaria a Academia Maranhense de Letras. É Martins (2006) quem nos esclarece alguns dos membros da Oficina: Antônio Lobo, Fran Pacheco, Astolfo Marques, João Quadros, Nascimento Moraes, dentre outros.

Era bastante comum, por essa época, que os cinematógrafos tomassem parte em eventos cívicos, festas religiosas de largo, efemérides públicas. E, normalmente, eram exibidos como uma parte da atração geral. Como foi o caso do Bioscópio na noite das comemorações alusivas ao 28 de julho, em que ele compôs o terceiro ato.

Foi também em uma festa pública que ocorreu a primeira filmagem feita por um projecionista maranhense, o senhor Rufino Coelho, que deu apresentações do seu Cinematógrafo Parisiense em duas ocasiões: de 28 de agosto a 11 de setembro de 1906 e de 20 a 23 de abril de 1907. Na primeira passagem, Rufino instalou o seu divertimento em pleno largo da Festa dos Remédios, então a festa religiosa mais tradicional da cidade. Lá, de acordo com o registro da Pacotilha, de 11.09.1906, filmou e projetou as seguintes vistas:

Festa dos Remedios -

Ainda hontem tivemos uma noite de festa, a do lava-pratos que, valha a verdade, correu com bastante animação.

Elegantes senhoritas, flores, luzes, musicas, tudo o que encanta e inebria a alma, havia em profusão, dando realce e brilho ao festival.

A kermesse esteve regularmente movimentada.

Ás 11 horas, depois de varias projecções cinematographicas, que muito agradaram aos assistentes, terminou a festividade.

Entre as vistas do cinematographo figuraram o pavilhão da Kermesse, a imagem de N.S. dos Remedios e, por ultimo, o retrato do sr. Commendador Augusto Marques, o incançavel promotor do triduo, por baixo do qual se liam as palavras - agradece, penhorado. (PACOTILHA, 11 set. 1906, s.p., grifo nosso).

Era o segundo registro de filmagens do ciclo do cinema ambulante no Maranhão. E o derradeiro. Outras notícias de filmes maranhenses só serão dadas depois de 1910, quando então São Luís entra em outra fase: a dos cinemas como 
salas de espetáculos, período registrado por Euclides Moreira Neto no seu livro "Primódios do Cinema em São Luís" (1977).

\title{
Considerações finais: a trajetória de José Fillipi
}

Fazendo jus à tradição dos projecionistas ambulantes, José Fillipi continuou avançando Brasil adentro com sua diversão, ora em capitais, ora em cidades pequenas. Era a mecânica da diversão: à proporção que as capitais iam abrindo salas fixas de cinema, os projecionistas ambulantes iam procurando novos mercados, cada vez mais distantes e afastados do epicentro da vida urbana brasileira, carregando a máquina e vendendo a sua novidade para quem ainda não a tinha visto. Sobre esse movimento, há uma crônica de Humberto de Campos, magnífica, escrita em 1933, em que o autor maranhense relembra a passagem de um projecionista desses por Parnaíba-PI:

\begin{abstract}
Eu de mim recordo-me perfeitamente dos primeiros filmes que fui espectador. $\mathrm{O}$ exibidor ambulante, dos muitos e beneméritos que percorriam então os sertões brasileiros, levando a mais surpreendente novidade da época, fora à cidade piauiense de Parnaíba. Era nos primeiros dias de 1903. Não me lembro se do programa constavam dramas e comédias. Sei, apenas, que oferecia na tela, a reprodução de acontecimentos consideráveis naquela hora do mundo, distinguindose, entre eles, pela nitidez e pela imponência do espetáculo, as marchas e cargas da cavalaria inglesa que efetivava, então, a ocupação militar do Transvaal. A guerra dos boers já havia terminado há quase um ano, mas os combatentes continuavam ainda em quadriláteros de pano comovendo os homens pelo interior do Brasil. (VIANY, 1993, p.133 apud BARRO, 2000, p. 113).
\end{abstract}

Entre esses está José Fillipi. Pelos registros cotejados dos jornais e livros, é possível rastrear um pouco a trajetória desse italiano que, como muitos outros, brasileiros e estrangeiros, enveredou pelos caminhos da cinematografia e pelo sonho do ganho fácil e rápido trazido pelas imagens em movimento. Além de ter passado por Belém, chegado a São Luís e seguido para o Ceará, provavelmente Fortaleza, encontramos registros de sua passagem por mais duas capitais: Salvador, em dezembro de 1902, e Curitiba, em 23 de agosto de 1903. As duas últimas passagens estão no levantamento primoroso de Máximo Barro, "Na Trilha dos Ambulantes" (2000), que ainda mapeia a trajetória dos principais projecionistas ambulantes do Brasil até 1905.

Não foi o único. Pela leitura dos autores que se debruçam sobre o início do 
cinema no Brasil, é possível perceber a profusão de nomes e sobrenomes estrangeiros que se apresentavam como empresários de aparelhos cinematográficos, alguns inclusive agregando ao aparelho o seu próprio nome (Cinematógrafo Kaurt; Cinematógrafo Hervet). O levantamento de Barro (2000) deixa entrever alguns projecionistas estrangeiros que rodavam pelo país com suas máquinas maravilhosas: Frederico Figner; Henry Paille; G. Renouleau; Frank Post; W. Rochert; Bernard Bluhm; Moura Quineau; J. Barucci; Schultz e Korler, etc. Dentre esses, alguns italianos: Francesco di Paola; Vito de Maio; Nicola Maria Parente; Paschoal Segreto e, claro, Giuseppe Felipe ou José Fillipi, como os jornais maranhenses denominaram o empresário do Bioscópio Inglês.

Além de ter tido o pioneirismo da filmagem em terras maranhenses, José Fillipi tem ainda outra qualidade que o diferencia. Exibiu, na avaliação dos jornais, o melhor cinematógrafo que passou por São Luís durante os 11 anos que durou o ciclo do Cinema Ambulante, tanto pela performance do aparelho quanto pela qualidade das vistas e do seu desempenho como empresário de entretenimento. Enfim, uma conjugação de aspectos o beneficiou. Tanto que, um ano depois da sua partida, quando da chegada de outro aparelho na cidade (o Bioscópio Ítalo-Brasileiro), a imprensa ainda se lembrava do Bioscópio Inglês com alguma reverência:

\footnotetext{
Bioscope -

A Companhia d'Arte dará amanhã no Theatro S. Luiz, o seu primeiro espectaculo, com o variado programma que está sendo distribuido.

É de crer que haja a maior concorrencia, chamada pelo genero de diversão que tanto agradou quando foi offererica pelo italiano $J$. Felippi, agora augmentada com novidades.

Produziu o melhor resultado a experiencia feita hontem com a luz electrica.

(DIÁRIO DO MARANHÃO, 23 set. 1903, s.p., grifo nosso).
}

Em tudo e por tudo, o Bioscópio Inglês e seu empresário, José Fillipi, com suas duas singularidades: a de ter deixado na cidade a melhor das impressões sobre a nova arte que surgia como fruto da modernidade e a de ter se tornado o primeiro a filmar e exibir cenas maranhenses, deixaram sua marca na história do cinema no Maranhão.

Cabe, ainda, considerar a importância, tanto dele quanto de muitos outros projecionistas que fizeram parte dos primeiros anos da cinematografia no Maranhão, para o estabelecimento e a consolidação do gênero de diversão (o primeiro propriamente "de massa" no mundo) entre os ludovicenses. Entre os anos de 1898 e 
1909, as companhias de teatro e de cinematógrafos foram os mais constantes espetáculos a visitar a capital do Maranhão.

Isso "domesticou" o olhar da sociedade para o cinema. Prática que vai se verificar no movimento posterior, que inicia no fim de 1909, com a criação da primeira sala de cinema na cidade: O Cinema São Luís, em 31.11.1909. É o que registra essa crônica da Pacotilha:

Diversões - Hontem os cinemas estiveram à cunha. Mal ia terminando uma sessão e já numerosos espectadores aguardavam a seguinte. Em frente ao S. Luiz, ao Ideal e ao Pathé, notava-se um desuzado movimento. A nossa população já vai compreendendo que é preciso sair de caza, ao menos uma vez por semana, provando as distrações mais ao alcance do bolso.

(PACOTILHA, 22 ago. 1910, s.p.).

Em todo o mundo, os cinematógrafos e seus "empresários" tiveram uma importância capital para a transformação da diversão "excêntrica" em indústria de entretenimento.

Submetido em: 22.06.2017

Aceito em: 11.10.2016

\section{REFERÊNCIA BIBLIOGRÁFICA}

ARAÚJO, Vicente de Paula. A bela época do cinema brasileiro. São Paulo: Brasiliense, 1985.

. Salões, circos e cinemas de São Paulo. São Paulo: Brasiliense, 1981.

BARRO, Máximo. Na trilha dos ambulantes. São Paulo: Editora Maturidade, 2000.

CAPELLARO, Jorge, J.V; FERREIRA, Paulo Roberto. Verdades sobre o início do cinema no Brasil. Rio de Janeiro: Funarte, 1996.

COSTA, Flávia Cesarino. O primeiro cinema. São Paulo: Scritta, 2005.

DIÁRIO DO MARANHÃO. São Luís, 14 jul. 1902, s.p.

. São Luís, 09 ago. 1902, s.p.

. São Luís, 23 set. 1903, s.p.

FOIRET, Jacques; BROCHARD, Philippe. Os irmãos Lumière e o cinema. São Paulo: Augustus, 1995. 
MARTINS, Manoel Barros. Operários da saudade: os novos atenienses e a invenção do Maranhão. São Luís: EDUFMA, 2006.

MATOS, Marcos Fábio Belo. Ecos da modernidade: uma análise do discurso sobre o cinema ambulante em São Luís. Passo Fundo: Méritos, 2016.

....E o cinema invadiu a athenas: a história do cinema ambulante em São Luís (1898-1909). São Luís: FUMC, 2002.

MANNONI, Laurent. A grande arte da luz e da sombra: arqueologia do cinema. São Paulo: Senac, Unesp, 2003.

MOREIRA NETO, Euclides Barbosa. Primórdios do cinema em São Luís. São Luís: Cineclube Uirá, 1977.

O FEDERALISTA. São Luís, 15 jul. 1902, s.p.

. São Luís, 18 jul. 1902, s.p.

. São Luís, 29 jul. 1902, s.p.

PACOTILHA. São Luís, 09 abr. 1898, s.p.

. São Luís, 05 jul. 1902, s.p.

. São Luís, 14 jul. 1902, s.p.

. São Luís, 11 set. 1906, s.p.

. São Luís, 23 abr 1907, s.p.

. São Luís, 24 abr. 1909, s.p.

. São Luís, 22 ago. 1910, s.p. 